\title{
Feeding Soybean Oil to Dairy Goats Increases Conjugated Linoleic Acid in Milk
}

\author{
M. A. Bouattour, R. Casals, ${ }^{1}$ E. Albanell, X. Such, and G. Caja \\ Grup de Recerca en Remugants, Departament de Ciència Animal i dels Aliments, Universitat Autònoma de Barcelona, \\ 08193 Bellaterra, Catalonia, Spain
}

\begin{abstract}
A total of 24 Murciano-Granadina dairy goats milked once daily throughout lactation were used to study the effects of including soybean oil (SBO) in the diet on lactational performance and milk fatty acid (FA) content, particularly conjugated linoleic acid (CLA) and trans-vaccenic acid (trans-11 C18:1, TVA). Three weeks after parturition, goats were allocated to 2 balanced groups according to lactation number, body weight, and daily milk yield, and were kept in separate pens. The experiment consisted of a 2-period ( $28 \mathrm{~d}$ each) crossover with 2 dietary treatments: control and SBO (6\% as fed in the concentrate). Goats were fed dehydrated fescue (ad libitum), alfalfa pellets $(0.5 \mathrm{~kg} / \mathrm{d})$, and concentrate $(1 \mathrm{~kg} / \mathrm{d})$ to which the SBO was or was not added. Forage was fed in the pens, and concentrate was fed individually in 2 equal portions at milking $(0900 \mathrm{~h})$ and in the afternoon (1700 h). Final SBO content in the consumed SBO diet was $2.5 \%$ (dry matter basis). Diets were isonitrogenous ( $17.4 \%$ crude protein), but their total FA content varied from $2.2 \%$ (control) to $4.6 \%$ (SBO). There was no effect of SBO on dry matter intake, milk yield, energy-corrected milk, body weight, or body condition score. Compared with the control diet, feeding SBO increased milk fat content (4.57 vs. $5.24 \%$ ) and yield as well as total solids content. Soybean oil had no effect on milk crude and true protein contents, but it reduced milk casein content ( 2.48 vs. $2.34 \%$ ). Short- and medium-chain FA decreased by feeding SBO, whereas long-chain FA increased. Feeding preformed linoleic acid through SBO increased milk concentrations of linoleic, oleic, and stearic FA but reduced levels of linolenic and palmitic FA. As a consequence, feeding SBO decreased the saturated-to-unsaturated FA ratio and the atherogenicity index. Compared with the control treatment, milk contents of cis-9, trans-11 CLA (0.68 vs. $2.03 \%)$ and TVA (2.04 vs. $6.41 \%)$ in the SBO treatment
\end{abstract}

Received October 4, 2007.

Accepted January 29, 2008.

${ }^{1}$ Corresponding author: ramon.casals@uab.cat increased by approximately $200 \%$. In conclusion, feeding a moderate dose of SBO to dairy goats was a useful way to increase milk fat, CLA, and TVA contents in milk and to reduce the atherogenicity index without negative effects on intake, milk yield, and protein content.

Key words: soybean oil, conjugated linoleic acid, milk fat, dairy goat

\section{INTRODUCTION}

Milk and dairy products from goats are important for proper human nutrition, especially for people with food allergies or those living in dry areas where cow's milk is not easy to produce. Dairy goat farming is of relevant economic importance in the Mediterranean area, where developed countries such as France, Italy, Spain, and Greece have an important dairy goat industry, with an increasing demand for gourmet cheeses, yogurt, and milk from sheep and goats (Haenlein, 2001). In addition, there is an interest in value-added products such as artisanal farmhouse dairy products and those enriched with polyunsaturated fatty acids (PUFA) or conjugated linoleic acid (CLA), which could offer potential benefits in terms of human health.

Conjugated linoleic acid refers to several isomers of linoleic acid (C18:2) containing a double unsaturation in a conjugated configuration and existing in the fat of ruminant milk and meat and in derivate products. Several studies have investigated, basically in animal models, the possible beneficial effects of CLA on human health, which are its anticarcinogenic, antiatherogenic, and antidiabetic (type II) properties; alteration of nutrient partitioning and lipid metabolism; reduction of hyperglycemia; immune modulation; and improvement of bone mineralization (McGuire and McGuire, 2000; Pariza et al., 2001). The properties of CLA are related to specific CLA isomers. Studies have established that rumenic acid (cis-9, trans-11 CLA), the major isomer in the milk fat of ruminants, is especially anticarcinogenic (Ip et al., 1999). The effects of CLA on nutrient partitioning and lipid metabolism are elicited by the trans10, cis-12 CLA isomer (Park et al., 1999), and the antidi- 
abetic effect is also induced by the trans-10, cis-12 CLA isomer (Ryder et al., 2001).

Factors related to variation in the CLA content of milk have been studied mainly in dairy cows (Dhiman et al., 1999; Chilliard et al., 2001; Kelsey et al., 2003) and are basically dietary factors, especially forage type and fat source (e.g., seeds, oils, calcium soaps, and others), and physiological factors, such as breed and lactation stage. Regarding dietary factors, different lipid precursors of CLA biosynthesis in the rumen have been evaluated. In dairy cows, the use of unsaturated fat generally increases CLA in milk more than when saturated fat is used. Chouinard et al. (2001) compared the effect of 3 types of calcium soaps made of different vegetable oils [canola oil, soybean oil (SBO), and linseed oil] and observed an increase in CLA content in milk caused by oil supplementation, with the response being higher with SBO and linseed oil. These results could be a consequence of the higher levels of PUFA (C18:2 and C18:3) in these substrates. In fact, biosynthesis of CLA can happen basically in 2 ways (Bauman et al., 2001): the first is the partial biohydrogenation of unsaturated fatty acids (FA) in the rumen, and the second, proposed later, is the desaturation of trans-11 C18:1 (TVA; trans-vaccenic acid), a product of rumen biohydrogenation, in the mammary gland by the action of $\Delta^{9}$-desaturase (Griinari et al., 2000). Lock and Bauman (2004) mentioned that TVA helps to prevent cancerous tumors once it has been desaturated to $c i s-9$, trans- 11 CLA, and TVA has been considered a component of functional dairy foods for its direct correlation with the biosynthesis of CLA (Bauman and Lock, 2006). However, this is not the case for all trans FA; the intake of some trans FA is associated with higher risk factors for cardiovascular diseases and biomarkers of inflammation, but the specific trans FA isomers responsible have not been identified (Kramer et al., 2006).

Research data on factors affecting milk CLA in dairy goats are less available than in dairy cows and have been reported mainly by French researchers (Chilliard et al., 2006). According to these studies, done basically with Alpine dairy goats, when fat sources such as C18:1 or C18:2 sunflower oil or linseed oil were tested, the main factor of variation was the nature of the oil, with higher CLA levels being obtained when sunflower oil (C18:2-rich) was fed. In contrast, raw, extruded, or formaldehyde-treated oilseeds gave poorer results (Chilliard et al., 2006), with milk CLA content also depending on the nature of the forage. Moreover, different effects of vegetable oils on CLA and TVA contents in the milk of dairy goats should be expected according to breed, as reported for milk FA profiles in dairy cows (Beaulieu and Palmquist, 1995; DePeters et al., 1995).
Table 1. Ingredients of the experimental concentrates containing or not containing soybean oil (SBO)

\begin{tabular}{lcr}
\hline & \multicolumn{2}{c}{ Concentrate } \\
\cline { 2 - 3 } Ingredient, \% as fed & Control & SBO \\
\hline Ground corn & 38.47 & 38.47 \\
Ground barley & 28.09 & 19.50 \\
Soybean meal (44\%) & 28.09 & 30.68 \\
SBO & - & 6.00 \\
Dicalcium phosphate & 0.93 & 0.93 \\
Calcium carbonate & 1.31 & 1.31 \\
Magnesium oxide & 0.37 & 0.37 \\
Sodium bicarbonate $^{1}$ & 0.94 & 0.94 \\
Minerals and vitamins $^{1}$ & 1.80 & 1.80 \\
\hline
\end{tabular}

${ }^{1}$ Mineral and vitamin complement, containing copper $(800 \mathrm{mg} / \mathrm{kg})$, manganese $(5,000 \mathrm{mg} / \mathrm{kg})$, zinc $(4,000 \mathrm{mg} / \mathrm{kg})$, vitamin A (750,000 IU/ $\mathrm{kg})$, vitamin D (150,000 IU/kg), vitamin E (5,000 IU/kg), and sepiolite as excipient.

The aim of this study was to investigate the effects of including SBO in the concentrate on the lactational performance and milk FA profile of Spanish MurcianoGranadina dairy goats, with special attention given to CLA and TVA contents in milk.

\section{MATERIALS AND METHODS}

\section{Animals, Feeding, and Experimental Design}

Twenty-four Murciano-Granadina goats (10 primiparous and 14 multiparous) from the herd of the Universitat Autònoma de Barcelona (UAB) were used in a milking trial early in the lactation. The experiment was approved by the Ethics Committee on Animal and $\mathrm{Hu}-$ man Experimentation of the UAB (reference no. CEEAH 04/481) and was performed from wk 3 to 11 of lactation.

After parturition, kids were separated from their mothers within the first $8 \mathrm{~h}$ after birth, and then were reared artificially with milk substitutes. After $21 \pm 7$ DIM, the goats ( $40.5 \pm 5 \mathrm{~kg}$ of BW) were divided into 2 groups according to parity, BW, and daily milk yield, recorded at wk 2 and 3 . The study was conducted according to a $2 \times 2$ crossover design, with 2 periods of $28 \mathrm{~d}$ each $(14 \mathrm{~d}$ for adaptation and $14 \mathrm{~d}$ for sampling and data recording). During the experiment, each group of goats was kept in a separate pen with food and fresh water available continually. In period 1, each group was randomly assigned to 1 of the 2 dietary treatments: control or SBO (6\% of SBO as fed in the concentrate), with the treatments switched in period 2. With the SBO diet, the oil was incorporated into the concentrate (Table 1) during manufacturing. The concentrates and final diets were formulated to be isonitrogenous (Table 2 ), but with different levels of ether extract and total FA (Table 3). Goats received a basal diet of dehydrated 
Table 2. Chemical composition and nutritional value of forages, experimental concentrates, and consumed diets (DM basis) of dairy goats containing or not containing soybean oil (SBO)

\begin{tabular}{|c|c|c|c|c|c|c|}
\hline \multirow[b]{2}{*}{ Item } & \multirow{2}{*}{$\begin{array}{l}\text { Dehydrated } \\
\text { fescue }\end{array}$} & \multirow{2}{*}{$\begin{array}{l}\text { Alfalfa } \\
\text { pellets }\end{array}$} & \multicolumn{2}{|c|}{ Concentrate } & \multicolumn{2}{|c|}{ Diet } \\
\hline & & & Control & $\mathrm{SBO}$ & Control & SBO \\
\hline DM, \% as fed & 90.76 & 90.92 & 89.18 & 90.29 & 90.14 & 90.60 \\
\hline Ash, \% & 11.37 & 12.83 & 8.53 & 8.96 & 10.59 & 10.75 \\
\hline $\mathrm{CP}, \%$ & 13.55 & 16.44 & 20.54 & 20.77 & 17.32 & 17.45 \\
\hline Ether extract, \% & 2.49 & 1.88 & 4.58 & 10.25 & 3.18 & 5.62 \\
\hline Total fatty acids, $\%$ & 1.30 & 1.20 & 3.60 & 9.10 & 2.23 & 4.57 \\
\hline $\mathrm{NDF}, \%$ & 58.99 & 47.31 & 13.46 & 11.39 & 36.52 & 35.36 \\
\hline $\mathrm{ADF}, \%$ & 31.11 & 33.42 & 5.45 & 4.68 & 21.02 & 20.51 \\
\hline $\mathrm{NE}_{\mathrm{L}},{ }^{1} \mathrm{Mcal} / \mathrm{kg}$ of $\mathrm{DM}$ & 1.17 & 1.14 & 1.84 & 2.10 & 1.44 & 1.55 \\
\hline
\end{tabular}

${ }^{1} \mathrm{NRC}(2001)$.

fescue (ad libitum) and $0.5 \mathrm{~kg}$ of alfalfa pellets, offered twice daily ( 0930 and $1730 \mathrm{~h}$ ), in a pen feeder equipped with a feeder lock. In addition, $1.0 \mathrm{~kg} / \mathrm{d}$ of experimental concentrate was offered individually in the milking parlor feeders in 2 equal portions of $0.5 \mathrm{~kg} / g$ oat at 0900 and $1700 \mathrm{~h}$. Both concentrates were highly palatable and were entirely consumed in the milking parlor; therefore, orts represented the forage portion of the diet only.

Animals were milked once daily $(0900 \mathrm{~h})$ in a double12 stall parallel milking parlor (Westfalia Landtechnik, Granollers, Spain) with recording jars and down-milk pipeline. Milking was conducted at a vacuum pressure of $42 \mathrm{kPa}$, a pulsation rate of $90 \mathrm{pulses} / \mathrm{min}$, and a pulsation ratio of $66 \%$. The milking routine included machine milking, machine stripping before cluster removal, and teat dipping.

\section{Measurement, Sampling, and Analysis}

Voluntary feed intake was registered throughout the experiment, but only sampling period data (last $14 \mathrm{~d}$ ) were considered. Group DMI was calculated as the difference between the total amounts of DM offered and the amount refused daily (accuracy $\pm 10 \mathrm{~g}$ ). Daily samples of diet ingredients and orts were collected and composited by period throughout the experiment. Feed and ort samples were ground through a 1-mm stainless steel screen and analyzed for DM and OM (AOAC, 1990). The CP was determined according to the Kjeldahl method (AOAC, 1990) by using a Kjeltec Auto 1030 Analyzer (Tecator, Hogänäs, Sweden). The NDF and ADF were determined (Van Soest et al., 1991) sequentially by using an Ankom system (Ankom Technology, Fairport, NY) with thermostable $\alpha$-amylase and sodium sulfite in the specific case of NDF, and corrected for ash. Analysis of the FA content of the feeds was performed according to Sukhija and Palmquist (1988), with nonadecanoic acid as an internal standard.
Milk yield was registered on d 1, 3, 5, 8, and 10 of each sampling period, and individual milk samples were collected at each milk yield recording. Milk samples $(100 \mathrm{~mL})$ were preserved with 2 tablets of Bronopol (BroadSpectrum Microtabs II, D\&F Control Systems Inc., San Ramon, CA). Samples were refrigerated at $4^{\circ} \mathrm{C}$ before being analyzed for TS, fat, total protein $(\mathrm{N}$ $\times 6.38$ ), true protein, and CN. Analysis was performed with a near-infrared spectroscopy analyzer (Technicon InfraAlyzer-450, Bran+Luebbe SL, Nordersted, Germany). Calibration was checked by using AOAC (1990) reference methods. On d 1, 3, 5, 8, and 10 of each sampling period, 2 additional milk samples were taken for each experimental period to analyze their FA profile. In this case, milk was immediately cooled and the fat fraction was separated by centrifugation for $30 \mathrm{~min}$ at $6,000 \times g$ and $4^{\circ} \mathrm{C}$, and then stored at $-20^{\circ} \mathrm{C}$. Milk FA were analyzed after extraction of milk fat samples and methylation (Palmquist and Jenkins, 2003) to avoid migration of conjugated double bonds of unsaturated FA. Briefly, milk fat samples (60 to $70 \mathrm{mg}$ ) were dissolved in $1 \mathrm{~mL}$ of benzene, and alkaline transesterification was completed by using $2 \mathrm{~mL}$ of $0.5 \mathrm{M}$ sodium methoxide in methanol $\left(10 \mathrm{~min}\right.$ at $\left.50^{\circ} \mathrm{C}\right)$. A second methylation with $3 \mathrm{~mL}$ of $100 \mathrm{~mL} / \mathrm{L}$ of methanolic $\mathrm{HCl}$ $\left(10 \mathrm{~min}\right.$ at $80^{\circ} \mathrm{C}$ ) followed. After addition of $1 \mathrm{~mL}$ of heptane and $7.5 \mathrm{~mL}$ of $60 \mathrm{~g} / \mathrm{L}$ of $\mathrm{K}_{2} \mathrm{CO}_{3}$ and centrifugation, the top solvent layers were transferred to a tube, $1 \mathrm{~g}$ of $\mathrm{Na}_{2} \mathrm{SO}_{4}$ was added, and the samples were centrifuged at $6,000 \times g$ and $4^{\circ} \mathrm{C}$. The clear layers containing the FA methyl esters (FAME) were transferred to 1-mL autosampler vials and stored at $-20^{\circ} \mathrm{C}$ until analysis. Separation and quantification of the FAME was carried out by using a gas chromatograph (HP 6890, Agilent Technologies, Palo Alto, CA) equipped with a flameionization detector and capillary column (CP-Sil-88, $100 \mathrm{~m} \times 0.25 \mathrm{~mm}$ i.d. with a $0.20-\mu \mathrm{m}$ capillary thickness; Varian Inc., Palo Alto, CA). The initial temperature of $70^{\circ} \mathrm{C}$ (for $1 \mathrm{~min}$ ) was increased to $225^{\circ} \mathrm{C}$ (for $15 \mathrm{~min}$ ) 


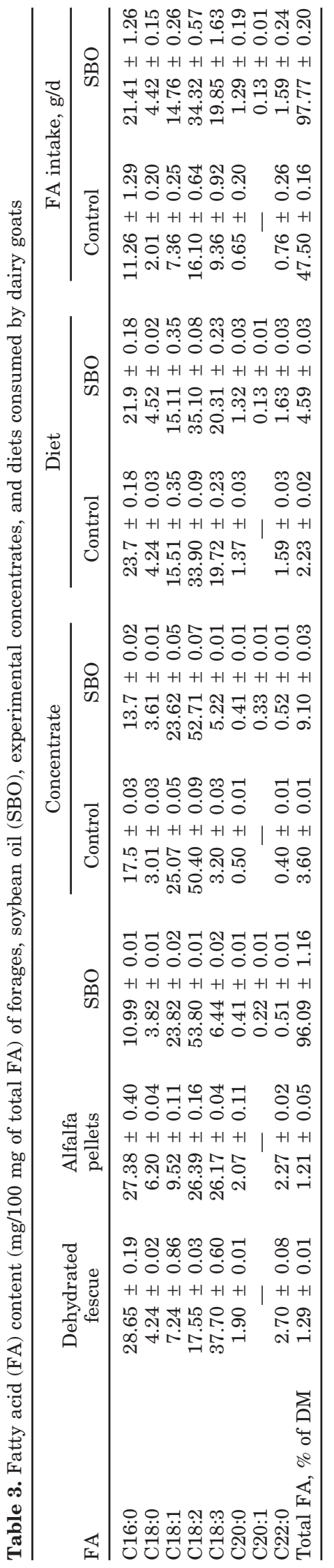

at a rate of $1{ }^{\circ} \mathrm{C} / \mathrm{min}$. Individual $\mathrm{FA}$ were identified by comparison of retention times with those of pure standards (Sigma-Aldrich Química, Madrid, Spain) and expressed as percentages of the total FA detected as FAME. In the particular cases of CLA and vaccenic acid identification, 2 standards were used for each, respectively, the cis-9, trans- 11 and the trans-10, cis-12 isomers of CLA (Matreya Inc., State College, PA) and the cis-11 C18:1 and the trans-11 C18:1 isomers of vaccenic acid (Sigma-Aldrich Inc., St Louis, MO).

Individual goat BW (accuracy $\pm 0.1 \mathrm{~kg}$ ) and BCS were recorded at the start and end of each experimental period. The BCS was measured on a 0 - to 5-point scale (accuracy \pm 0.25 ) by palpating the lumbar, caudal, and chest regions according to Hervieu et al. (1991).

\section{Statistical Analysis}

Individual data for BW, BCS, milk yield, and milk composition, and group data for DMI were analyzed by using the PROC MIXED procedure of SAS with repeated measures (version 8.2; SAS Institute Inc., Cary, NC), using Tukey's multiple comparison test. The statistical model contained the fixed effects of treatment, experimental period, and treatment sequence, the random effects of the animal, and the residual error. Differences were declared significant at $P<0.05$.

\section{RESULTS AND DISCUSSION}

Some differences $(P<0.05)$ were observed between primiparous and multiparous goats with regard to milk yield, total milk protein content, BW, BCS, and some FA, such as palmitic, stearic, oleic, and linoleic acids. However, this effect did not have any significant interaction with the investigated treatments. Therefore, only the main effects are discussed.

\section{Feed Intake and Nutritive Value of Diets}

As expected, both the control and SBO concentrates (20.6\% CP) and diets (17.4\% CP) were isonitrogenous and had very similar contents of DM, OM, NDF, and $\mathrm{ADF}$ (Table 2). As a direct consequence of the incorporation of oil, the SBO concentrate contained higher ether extract (4.6 vs. $10.3 \%$ ), total FA (3.6 vs. $9.1 \%$ ), and $\mathrm{NE}_{\mathrm{L}}$ (1.84 vs. $2.10 \mathrm{Mcal} / \mathrm{kg}$ ) contents than did the control concentrate (Table 2). According to the observed intake of diet ingredients, we calculated that the forage-toconcentrate ratio of diets was close to 58:42 (58.1:41.9 vs. 57.4:42.6), with the SBO diet containing $2.5 \%$ soybean oil (DM basis) and a higher total FA content than the control (2.2 vs. $4.6 \%$; Table 2 ), with an average supplementary $\mathrm{NE}_{\mathrm{L}}$ intake of $0.22 \mathrm{Mcal} /$ goat per day. 
These differences in total FA and energy contents of experimental concentrates and diets could be avoided if calcium soaps of FA or other inert fats were included in the control concentrate, but when the present experiment was planned, we had no information on the possible effects of calcium soaps on the CLA content of milk, and no fat supplements were included in the control treatment. Despite these changes in diet composition, feeding SBO did not change the total DMI (2.13 vs. 2.12 $\pm 0.01 \mathrm{~kg} / \mathrm{d}$ ), in agreement with the results described by Jenkins and Fotouhi (1990) when feeding a similar dose $(2.4 \%)$ of corn oil to wethers. However, Kitessa et al. (2001), who fed fish oil to goats, observed a DMI depression caused by fat supplementation. In general, DMI is usually affected when high levels of fat or strong flavor sources such as fish oil are used. In our case, the moderate SBO level (2.5\% of total DM in the diet) and the high NDF content of the diets could explain the neutral effect of the SBO diet on DMI.

\section{$B W$ and $B C S$}

Changes in both BW and BCS were positive throughout the experimental periods of the study, indicating that animals were, on average, under a positive energy balance. The BW (40.6 vs. $40.4 \pm 1.04 \mathrm{~kg})$ and BCS (2.70 vs. $2.67 \pm 0.07$ units) were not changed by the SBO treatment in spite of the higher $\mathrm{NE}_{\mathrm{L}}$ content for the SBO diet. Data relating the effects of lipid supplementation on goat BW changes during early lactation are limited, and responses are usually variable and not constant. In fact, BW gain was higher than in our experiment when using calcium salts of FA (Baldi et al., 1992) but was unchanged with vegetable sources (Chilliard et al., 2003). Regarding BCS, few data are available on this parameter in fat supplementation studies with dairy goats.

\section{Dairy Performance}

Milk yield and composition data are shown in Table 4. Milk yield and ECM are expressed in kilograms after the application of an average milk density value corresponding to each treatment. The supplementation with SBO did not modify milk yield $(1.87 \mathrm{~kg} / \mathrm{d})$ and ECM $(2.03 \mathrm{~kg} / \mathrm{d})$. Contrary to the milk yield observed in dairy cows, where milk yield is usually increased when cows are fed fat supplements at mid or even late lactation (DePeters and Cant, 1992; Chilliard et al., 2001), goats did not increase milk yield, whereas milk fat content increased by $10 \%$. According to other studies carried out in dairy goats, diet supplementation with lipids did not modify milk yield (Mir et al., 1999).
Table 4. Effects of feeding soybean oil (SBO) on the milk yield and composition of dairy goats

\begin{tabular}{|c|c|c|c|c|}
\hline \multirow[b]{2}{*}{ Item } & \multicolumn{2}{|c|}{ Treatment } & \multirow[b]{2}{*}{ SEM } & \multirow{2}{*}{$\begin{array}{l}\text { Effec } \\
(P<)\end{array}$} \\
\hline & Control & SBO & & \\
\hline Milk yield, kg/d & 1.90 & 1.85 & 0.07 & NS \\
\hline $\mathrm{ECM}, \mathrm{kg} / \mathrm{d}$ & 2.03 & 2.15 & 0.07 & NS \\
\hline Fat, \% & 4.57 & 5.24 & 0.08 & $* * *$ \\
\hline Fat, g/d & 85.6 & 95.0 & 3.2 & * \\
\hline Protein, \% & 3.37 & 3.38 & 0.04 & NS \\
\hline Protein, $\mathrm{g} / \mathrm{d}$ & 63.3 & 61.8 & 2.2 & NS \\
\hline True protein, \% & 2.88 & 2.88 & 0.05 & NS \\
\hline True protein, $\mathrm{g} / \mathrm{d}$ & 54.1 & 52.8 & 0.2 & NS \\
\hline $\mathrm{CN}, \%$ & 2.48 & 2.34 & 0.05 & $* * *$ \\
\hline $\mathrm{CN}, \mathrm{g} / \mathrm{d}$ & 46.7 & 42.7 & 0.2 & * \\
\hline $\mathrm{CN}, \%$ of $\mathrm{CP}$ & 73.4 & 68.6 & 0.7 & $* * *$ \\
\hline $\mathrm{CN}, \%$ of true protein & 86.1 & 81.1 & 0.5 & $* * *$ \\
\hline TS, \% & 12.9 & 13.4 & 0.1 & $* * *$ \\
\hline TS, g/d & 244.3 & 248.6 & 8.15 & NS \\
\hline
\end{tabular}

${ }^{1}$ Effect: $* P<0.05 ; * * * P<0.001$.

As a consequence of SBO supplementation, milk fat content $(4.57$ vs. $5.24 \% ; P<0.001)$ and fat yield (86 vs. $95 \mathrm{~g} / \mathrm{d} ; P<0.05$ ) increased (Table 4$)$. The improvement in fat content of milk as a response to lipid supplementation agrees with the results of Morand-Fehr et al. (1987), who used prilled fat in goats at early lactation. The response obtained was higher than that in dairy cattle (Chilliard et al., 2001) but lower than that in dairy sheep (Bouattour et al., 2005). As has been suggested by Chilliard et al. (2003) with other sources of fat, this positive effect of SBO on milk fat content could be useful to solve technological problems in the goat cheese industry linked to the "inversion syndrome," when the fat content falls below the protein content. This did not happen in our case, but this problem is frequent when diets are poor in fiber or rich in NFC, which could be partially replaced by an oil supplement to increase milk fat content.

The response of milk fat secretion is usually higher during early lactation because de novo lipogenesis is usually more active after the lactation peak than before it. After the lactation peak, dietary FA would probably be partitioned more to the adipose tissue (Chilliard et al., 2003).

Milk total protein $(3.38 \%)$ and protein yield $(62 \mathrm{~g} / \mathrm{d})$, as well as true protein content $(2.88 \%)$ and yield (53.5 $\mathrm{g} / \mathrm{d})$, remained without changes; however, the SBO treatment decreased $(P<0.001) \mathrm{CN}$ content and yield, as well as the CN:total protein and $\mathrm{CN}$ :true protein ratios in milk (Table 4 ).

Milk protein content is usually reduced by fat supplements when these are fed to dairy cows (De Peters et al., 1987) or dairy ewes (Casals et al., 1999; Bouattour et al., 2005), and this reduction in milk protein may alter the renneting properties of the milk. In contrast 
to dairy cows and ewes, this negative effect of dietary fat on milk protein content seems to be unusual in dairy goats (Baldi et al., 1992; Chilliard et al. 2006), as observed in the present study. However, in our case it was difficult to explain the reduction in $\mathrm{CN}$ content and $\mathrm{CN}$ :protein ratio without modification of the milk true protein content. The reduction in milk $\mathrm{CN}$ content agrees with data reported by DePeters and Cant (1992) in dairy cows, but disagrees with the results of Chiofalo et al. (2004), who fed olive cake to dairy ewes and did not observe any change in milk $\mathrm{CN}$ content. Total solids content was increased by the SBO treatment, probably as a consequence of the observed fat content increase and the stable levels of milk yield and milk protein content.

\section{Milk FA}

Data on the FA content of milk from the MurcianoGranadina goats is shown in Table 5. Fatty acids were classified according to chain length as follows: shortchain FA (between $\mathrm{C} 4$ and C10), medium-chain FA (between $\mathrm{C} 12$ and C16), and long-chain FA (more than 16 carbons). The SBO diet decreased $(P<0.001)$ short- and medium-chain FA and increased $(P<0.001)$ long-chain FA in the milk. Moreover, the addition of SBO decreased $(P<0.001)$ saturated FA concentrations and increased $(P<0.001)$ unsaturated FA concentrations and monounsaturated FA (21.8 vs. $29.3 \%)$ and PUFA (3.73 vs. $4.15 \%)$ contents in the milk. Milk contents of stearic, oleic, and linoleic acids were increased, whereas the content of linolenic acid was decreased by SBO.

Most of the FA originating from mammary de novo synthesis are saturated (C10 to $\mathrm{C} 16)$, and long-chain FA usually strongly inhibit de novo synthesis (Chilliard et al., 2003). This effect is greater when long-chain FA are unsaturated, as in the case of the supplement (SBO) used in the present study. The FA profile of the SBO used was basically characterized by a high concentration of C18:2 (54\% of total FA), a relatively high content of C18:1 (22\%), and lower levels of C18:3 and C18:0. As a consequence, intakes of all C18 FA were higher in the SBO diet than in the control diet (Table 3). These differences in the FA composition of the diets may explain the increase in C18:2 content in milk from the SBO treatment. Nevertheless, the increase in C18:2 content was relatively low (14\%), whereas the C18:3 content was decreased even in the milk of goats receiving SBO, probably because of the ruminal biohydrogenation of these unsaturated FA. Opposite responses of C18:2 and C18:3 acids have been observed with different vegetable oil supplements, illustrating that the different PUFA are not secreted independently from each other (Chilliard et al., 2006). In accordance with the
Table 5. Effects of soybean oil (SBO) supplementation on the fatty acid (FA) composition of dairy goat milk (\% of total FAME $^{1}$ )

\begin{tabular}{|c|c|c|c|c|}
\hline \multirow[b]{2}{*}{ Item } & \multicolumn{2}{|c|}{ Treatment } & \multirow[b]{2}{*}{ SEM } & \multirow{2}{*}{$\begin{array}{l}\text { Effect } \\
(P<)^{2}\end{array}$} \\
\hline & Control & SBO & & \\
\hline $\mathrm{C} 4: 0$ & 1.21 & 1.27 & 0.03 & + \\
\hline C6:0 & 1.99 & 1.99 & 0.05 & NS \\
\hline $\mathrm{C} 8: 0$ & 2.73 & 2.59 & 0.08 & NS \\
\hline $\mathrm{C} 10: 0$ & 10.83 & 8.97 & 0.25 & $* * *$ \\
\hline C12:0 & 6.30 & 4.30 & 0.15 & $* * *$ \\
\hline C14:0 & 11.28 & 8.66 & 0.18 & **** \\
\hline C14:1 & 0.22 & 0.13 & 0.02 & **** \\
\hline $\mathrm{C} 15: 0$ & 0.97 & 0.79 & 0.02 & $* * *$ \\
\hline $\mathrm{C} 16: 0$ & 27.46 & 22.57 & 0.41 & **** \\
\hline $\mathrm{C} 16: 1$ & 0.64 & 0.50 & 0.02 & **** \\
\hline $\mathrm{C} 17: 0$ & 0.65 & 0.56 & 0.01 & **** \\
\hline $\mathrm{C} 17: 1$ & 0.22 & 0.12 & 0.02 & $* * *$ \\
\hline $\mathrm{C} 18: 0$ & 9.09 & 12.41 & 0.35 & *** \\
\hline Trans-9 C18:1 & 0.18 & 0.74 & 0.05 & **** \\
\hline Trans-11 C18:1 $\left(\mathrm{TVA}^{3}\right)$ & 2.04 & 6.41 & 0.27 & $* * *$ \\
\hline Cis-9 C18:1 & 17.82 & 19.56 & 0.35 & $* * *$ \\
\hline Cis-11 C18:1 & 0.56 & 0.80 & 0.02 & $* * *$ \\
\hline Trans -10, trans -12 C18:2 & 0.31 & 0.42 & 0.02 & $* * *$ \\
\hline Cis-9, cis-12 C18:2 & 2.91 & 3.32 & 0.01 & ** \\
\hline Cis -9, trans -11 C18:2 $\left(\mathrm{CLA}^{4}\right)$ & 0.68 & 2.03 & 0.04 & $* * *$ \\
\hline C18:3 & 0.69 & 0.62 & 0.02 & *** \\
\hline $\mathrm{C} 20: 0$ & 0.26 & 0.29 & 0.01 & $* * *$ \\
\hline Other & 0.89 & 0.88 & 0.07 & NS \\
\hline$n-6: n-3$ & 4.69 & 6.12 & 0.16 & *** \\
\hline Short-chain FA (C4 to C10) & 16.90 & 14.91 & 0.38 & ** \\
\hline Medium-chain FA (C12 to $\mathrm{C} 16)$ & 47.04 & 37.09 & 0.59 & **** \\
\hline Long-chain FA (>C16) & 35.10 & 46.94 & 0.77 & *** \\
\hline Saturated FA & 72.84 & 64.47 & 6.47 & **** \\
\hline Unsaturated FA & 26.27 & 34.65 & 0.52 & *** \\
\hline Monounsaturated FA & 19.63 & 27.87 & 0.37 & *** \\
\hline Polyunsaturated FA & 4.60 & 6.40 & 0.12 & *** \\
\hline TVA:CLA & 2.99 & 3.17 & 0.18 & NS \\
\hline Atherogenicity index ${ }^{5}$ & 3.29 & 2.20 & 0.08 & $* * *$ \\
\hline \multicolumn{5}{|l|}{$\Delta^{9}$-Desaturase ratio $^{6}$} \\
\hline $\mathrm{C} 14$ & 0.017 & 0.014 & 0.001 & $*$ \\
\hline C16 & 0.023 & 0.021 & 0.001 & NS \\
\hline C18 & 0.69 & 0.69 & 0.006 & NS \\
\hline CLA & 0.26 & 0.25 & 0.015 & NS \\
\hline
\end{tabular}

${ }^{1}$ Fatty acid methyl esters.

${ }^{2}$ Effect: ${ }^{+} P<0.10 ; * P<0.05 ; * * P<0.01 ; * * * P<0.001$.

${ }^{3}$ Trans $=$ vaccenic acid.

${ }^{4}$ Conjugated linoleic acid.

${ }^{5}$ Calculated according to Ulbricht and Southgate (1991) as (C12 + $4 \times \mathrm{C} 14+\mathrm{C} 16) /(\Sigma$ unsaturated FA $)$.

${ }^{6}$ Calculated for each pair of FA according to Kelsey et al. (2003) as (product of $\Delta^{9}$-desaturase)/(product of $\Delta^{9}$-desaturase + substrate of $\Delta^{9}$-desaturase); that is, for C14:C14:1/(C14:1 + C14:0).

changes reported above, the $n-6: n-3$ ratio increased from 4.69 to 6.12 in the SBO group. According to the World Health Organization, the recommended range of the $n-6: n-3$ for human health is between $5: 1$ and $10: 1$.

The increases in C18:0 and C18:1 acids may, in part, be a consequence of higher intakes of these FA in the SBO diet, but may also be a result of the biohydrogenation process of unsaturated C18 FA in the rumen. Oleic acid can also be increased by the action of mammary $\Delta^{9}$-desaturase on C18:0. In addition, the important in- 
crease observed in C18:0 content in milk from the SBO treatment could be related to the higher level of milk fat observed in this treatment. As has been pointed out by Chilliard et al. (2006), C18:0 is a major regulating factor of mammary lipid secretion in goats and is positively correlated with milk fat content in that species. In Jersey and Holstein dairy cows receiving different levels of calcium salts of palm oil FA, the percentage of C18:1 increased in both breeds as dietary fat increased, but the percentage of C18:0 increased only in Jersey cows, indicating breed differences for fat utilization (Beaulieu and Palmquist, 1995).

The level of $c i s-9$, trans-11 CLA in the milk of goats fed SBO was almost 3 times greater than that in the control ( 0.68 vs. $2.03 \%$ of total FAME). In contrast, the trans-10, cis-12 CLA isomer was not detected in the milk fat samples. Chilliard et al. (2006) indicated that this isomer always remains at trace levels in goat milk. Rumenic acid is synthesized in the rumen during the biohydrogenation of linoleic acid, but it can also be obtained from the mammary gland by the desaturation action of $\Delta^{9}$-desaturase on TVA, another intermediate product of that process.

Milk TVA content increased by the effect of SBO supplementation $(2.04$ vs. $6.41 \% ; P<0.001)$ and the TVA:CLA ratio remained unchanged, showing that TVA and CLA evolved in the same way (Table 5). This would indicate that the action of $\Delta^{9}$-desaturase was relevant in milk CLA biosynthesis. There is generally a wide linear correlation between rumenic acid and TVA levels in milk under a wide variety of diets either in dairy goats (Chilliard et al., 2003; Nudda et al., 2005) or in dairy cows (Griinari et al., 2000).

In this study, the level of CLA in milk from control goats $(0.68 \%$ of total FAME) was in the range of normal values observed for goats receiving non-fat-supplemented diets (Chilliard et al., 2006). In contrast, CLA in milk from goats fed SBO (2.03\% of total FAME) was very close to the level described by Chilliard et al. (2006) when using sunflower oil. The same authors (Chilliard et al., 2006) indicated a considerable increase in CLA content (from 0.3 to $5.1 \%$ ) in goat milk with combinations of 5 different forages and with or without some oil addition. In this sense, the results obtained in Murciano-Granadina dairy goats are in the range of the levels of CLA and TVA observed in Alpine dairy goats. Levels of CLA similar to those obtained in the present study with SBO have been observed in dairy ewes (Bouattour et al., 2005) after SBO supplementation and in dairy cows fed either fresh pasture (Dhiman et al., 1999) or calcium soaps of SBO (Chouinard et al., 2001).

According to Chilliard et al. (2006), data on dairy cattle suggest that responses to lipid supplementation in terms of CLA and TVA could be transient, with the maximum values obtained during the first $2 \mathrm{wk}$ after beginning supplementation and decreasing after $3 \mathrm{wk}$. In goats, however, the same authors observed that the CLA response reached its maximum level $2 \mathrm{wk}$ after the beginning of supplementation and remained relatively high even after $10 \mathrm{wk}$ of lipid feeding. This indicates that goats are very good responders to unsaturated fat supplements and that the enhanced CLA level persists for at least 2 mo. These aspects can be especially important if goats have been genetically improved for genotype with high $\alpha_{\mathrm{s} 1}-\mathrm{CN}$. As shown by Chilliard et al. (2006), goats of the high $\alpha_{\mathrm{s} 1}$-CN genotype group usually have a lower content of CLA in milk than those with low $\alpha_{\mathrm{s} 1}-\mathrm{CN}$. Under these circumstances, feeding an unsaturated source of vegetable oil such as SBO can help to increase the CLA content of milk when goats are or have been genetically improved for a high $\alpha_{\mathrm{s} 1}-\mathrm{CN}$ genotype.

The desaturase indexes were not modified for C16:0, C18:1, and CLA, but were decreased $(P<0.05)$ for C14:0 when SBO was fed. This decrease could be a consequence of the increase observed in PUFA. The $\Delta^{9}$-desaturase indexes are generally lower in goat milk than in cow milk for medium-chain FA, but not for C18 FA, which could suggest a possible species dependence on the $\Delta^{9}$-desaturase activity according to chain length (Chilliard et al., 2006).

The atherogenicity index, calculated as $(\mathrm{C} 12+4 \times$ $\mathrm{C} 14+\mathrm{C} 16) /(\Sigma$ unsaturated FA), was reduced $(P<0.001$; Table 5) because of SBO supplementation. This index involving the supposed unhealthy saturated FA is considered to be an indicator of the dietary saturated FA risk factor for coronary heart disease (Ulbricht and Southgate, 1991). However, as discussed by Chilliard et al. (2006), the findings of several authors (Mensink et al., 2003; Knopp and Retzlaff, 2004) indicate that there is little evidence of an atherogenic effect of C12:0, C14:0, and C16:0 FA, and that saturated fat could even be protective when compared with a low-fat, high-carbohydrate diet. Therefore, this index, which was improved in the SBO diet, could be considered of interest in terms of human health only in cases in which there is excessive fat consumption.

\section{CONCLUSIONS}

When goats from typically dry areas, such as the Spanish Murciano-Granadina breed, were fed a relatively high-forage diet, adding a reasonable dose of SBO increased the fat and energy contents of the diet and allowed the production of enriched fat, CLA, and TVA in milk when compared with goats fed a non-fat-supplemented diet. No negative effects on DMI, milk yield, and milk protein content were observed, but milk CN 
content and yield were reduced. Feeding SBO could be a valuable tool for farmers of dairy goats under intensive feeding systems to produce milk and dairy products enriched in monounsaturated FA, PUFA, CLA, and TVA, which are considered healthier for human consumers.

\section{ACKNOWLEDGMENTS}

The authors are grateful to Ramon Costa and the team of the SGCE (Servei de Granges i Camps Experimentals, Bellaterra, Spain) of the UAB for the care of the animals, and to Nic Aldam for reviewing the manuscript. This study was partially funded by the Ministerio de Ciencia y Tecnología of Spain (CICYT project AGL2001-2617). M. Amine Bouattour was granted a scholarship from the AECI (Agencia Española de Cooperación Internacional, Spain).

\section{REFERENCES}

AOAC. 1990. Official Methods of Analysis. 15th ed. Vol. 1. Assoc. Off. Anal. Chem., Arlington, VA.

Baldi, A., F. Cheli, C. Corino, V. DellOrto, and F. Polidori. 1992. Effect of feeding calcium salts of long chain fatty acids on milk yield, milk composition and plasma parameters of lactating goats. Small Rumin. Res. 6:303-310.

Bauman, D. E., B. Corl, L. Baumgard, and J. Griinari. 2001. Conjugated linoleic acid (CLA) and the dairy cow. Pages 221-250 in Recent Advances in Animal Nutrition. P. C. Garnsworthy and J. Wiseman, ed. Nottingham University Press, Nottingham, UK.

Bauman, D. E., and A. L. Lock. 2006. Animal products and human health: Perceptions, opportunities and challenges. Pages 45-57 in Proc. Cornell Nutr. Conf. Feed Manuf., Syracuse, NY. Cornell Univ., Ithaca, NY.

Beaulieu, A. D., and D. L. Palmquist. 1995. Differential effects of high fat diets on fatty acid composition in milk of Jersey and Holstein cows. J. Dairy Sci. 78:1336-1344.

Bouattour, M. A., R. Casals, E. Albanell, E. González, X. Such, and G. Caja. 2005. Effects of fibrolytic enzymes and soybean oil on dairy sheep performance and nutrient digestibility. J. Dairy Sci. 88(Suppl. 1):308. (Abstr.)

Casals, R., G. Caja, X. Such, C. Torre, and S. Calsamiglia. 1999. Effects of calcium soaps and rumen undegradable protein on the milk production and composition of dairy ewes. J. Dairy Res. 66:177-191.

Chilliard, Y., A. Ferlay, and M. Doreau. 2001. Review: Effect of different types of forages, animal fat or marine oils in cow's diet on milk fat secretion and composition, especially conjugated linoleic acid (CLA) and polyunsaturated fatty acids. Livest. Prod. Sci. 70:31-48.

Chilliard, Y., A. Ferlay, J. Rouel, and G. Lamberet. 2003. A review of nutritional and physiological factors affecting goat milk lipid synthesis and lipolysis. J. Dairy Sci. 86:1751-1770.

Chilliard, Y., J. Rouel, A. Ferlay, L. Bernard, P. Gaborit, K. RaynalLjutovac, A. Lauret, and C. Leroux. 2006. Optimising goat milk and cheese fatty acid composition. Pages 281-232 in Improving the Fat Content of Foods. C. Williams and J. Buttriss, ed. Woodhead Publishing Limited, Cambridge, UK.

Chiofalo, B., L. Liotta, A. Zumbo, and V. Chiofalo. 2004. Administration of olive cake for ewe feeding: Effect on milk yield and composition. Small Rumin. Res. 55:169-176.

Chouinard, P. Y., L. Corneau, W. R. Butler, Y. Chilliard, J. K. Drackley, and D. E. Bauman. 2001. Effect of dietary lipid source on conjugated linoleic acid concentrations in milk fat. J. Dairy Sci. 84:680-690.
DePeters, E. J., and J. P. Cant. 1992. Nutritional factors influencing the nitrogen composition of bovine milk: A review. J. Dairy Sci. 75:2043-2070.

DePeters, E., J. F. Medrano, and B. A. Reed. 1995. Fatty acid composition of milk fat from three breeds of dairy cattle. Can. J. Anim. Sci. 75:267-269.

DePeters, E. J., S. J. Taylor, C. M. Finley, and T. R. Famula. 1987. Dietary fat and nitrogen of milk from lactating cows. J. Dairy Sci. 70:1192-1204.

Dhiman, T. R., G. R. Anand, L. D. Satter, and M. W. Pariza. 1999. Conjugated linoleic acid content of milk from cows fed different diets. J. Dairy Sci. 82:2146-2156.

Griinari, J. M., B. A. Corl, S. H. Lacy, P. Y. Chouinard, K. V. Nurmela, and D. E. Bauman. 2000. Conjugated linoleic acid is synthesized endogenously in lactating dairy cows by $\Delta^{9}$-desaturase. J. Nutr. 130:2285-2291.

Haenlein, G. F. W. 2001. Past, present and future perspectives of small ruminant dairy research. J. Dairy Sci. 84:2097-2115.

Hervieu, J., P. Morand-Fehr, P. Schmidely, V. Fedele, and R. Delfa. 1991. Mesures anatomiques permettant d'expliquer les variations des notes sternales, lombaires et caudales utilisées pour éstimer l'état corporel des chèvres laitières. Options Méditerranéennes, Série Séminaires 13:43-56.

Ip, C., S. Banni, E. Angioni, G. Carta, J. McGinley, H. J. Thompson, D. Barbano, and D. E. Bauman. 1999. Conjugated linoleic acidenriched butter fat alters mammary gland morphogenesis and reduces cancer risk in rats. J. Nutr. 129:2135-2142.

Jenkins, T. C., and N. Fotouhi. 1990. Effects of lecithin and corn oil on site of digestion, ruminal fermentation and microbial protein synthesis in sheep. J. Anim. Sci. 68:460-466.

Kelsey, J. A., B. A. Corl, R. J. Collier, and D. E. Bauman. 2003. The effect of breed, parity and stage of lactation on conjugated linoleic acid (CLA) in milk fat from dairy cows. J. Dairy Sci. 86:2588-2597.

Kitessa, S. M., S. K. Gulati, J. R. Ashes, E. Fleck, T. W. Scott, and P. D. Nichols. 2001. Utilisation of fish oil in ruminants. II. Transfer of fish oil fatty acids into goat's milk. Anim. Feed Sci. Technol. 89:201-208.

Knopp, R. H., and B. M. Retzlaff. 2004. Saturated fat prevents coronary artery disease? An American paradox. Am. J. Clin. Nutr. 80:1102-1103.

Kramer, J. K. G., C. Cruz Hernandez, and M. E. R. Dugan. 2006. Trans-PUFA isomers, analytical aspects, occurrence in plant and animal lipids. Page 34 in Proc. 4th Eur. Fed. Lipids Congr., Madrid, Spain. Eur. Fed. Lipid, Frankfurt, Germany.

Lock, A. L., and D. E. Bauman. 2004. Modifying milk fat composition of dairy cows to enhance fatty acids beneficial to human health. Lipids 39:1197-1206.

McGuire, M. A., and M. K. McGuire. 2000. Conjugated linoleic acid (CLA): A ruminant fatty acid with beneficial effects on human health. Proc. Am. Soc. Anim. Sci. Annu. Mtg. 1999. http://www.asas.org/jas/symposia/proceedings/0938.pdf Accessed Jan. 27, 2008.

Mensink, R. P., P. L. Zock, A. D. M. Kester, and M. B. Katan. 2003. Effects of dietary fatty acids and carbohydrates on the ratio of serum total to HDL cholesterol and on serum lipids and apolipoproteins: A meta-analysis of 60 controlled trials. Am. J. Clin. Nutr. 77:1146-1155.

Mir, Z., L. A. Goonewardene, E. Okine, S. Jaegar, and H. D. Scheer. 1999. Effect of feeding canola oil on constituents, conjugated linoleic acid (CLA) and long chain fatty acids in goats milk. Small Rumin. Res. 33:137-143.

Morand-Fehr, P., P. Bas, and D. Sauvant. 1987. Influence de la nature et de la quantité de lipides ajoutés à la ration sur la sécrétion de lait et de matière grasse chez la chèvre. Reprod. Nutr. Dev. 27:309-310.

NRC. 2001. Nutrient Requirements of Dairy Cattle. 7th. rev. ed. Natl. Acad. Sci., Washington, DC.

Nudda, A., M. A. McGuire, G. Battacone, and G. Pulina. 2005. Seasonal variation in conjugated linoleic acid and vaccenic acid in milk fat of sheep and its transfer to cheese and ricotta. J. Dairy Sci. 88:1311-1319. 
Palmquist, D. L., and T. C. Jenkins. 2003. Challenges with fats and fatty acid methods. J. Anim. Sci. 81:3250-3254.

Pariza, M. W., Y. Park, and M. E. Cook. 2001. The biologically active isomers of conjugated linoleic acid. Progr. Lipid Res. 40:283-298.

Park, Y., J. M. Storkson, K. J. Albright, W. Liu, and M. W. Pariza. 1999. Evidence that the trans-10, cis-12 isomer of conjugated linoleic acid induces body composition changes in mice. Lipids 34:235-241.

Ryder, J. W., C. P. Portocarrero, X. M. Song, L. Cui, M. Yu, T. Combatsiaris, D. Galuska, D. E. Bauman, D. M. Barbano, M. J. Char- ron, J. R. Zierath, and K. L. Houseknecht. 2001. Isomer-specific antidiabetic properties of conjugated linoleic acid. Diabetes 50:1149-1157.

Sukhija, P. S., and D. L. Palmquist. 1988. Rapid method for determination of total fatty acid content and composition of feedstuffs and feces. J. Agric. Food Chem. 36:1202-1206.

Ulbricht, T. L. V., and D. A. T. Southgate. 1991. Coronary heart disease: Seven dietary factors. Lancet 338:985-992.

Van Soest, P. J., J. B. Robertson, and B. A. Lewis. 1991. Methods of dietary fiber, neutral detergent fiber, and nonstarch polysaccharides in relation to animal nutrition. J. Dairy Sci. 74:3583-3597. 